\title{
Disaster Cooperation Strategies between North and South Korea based on Sendai Framework*
}

\author{
Junho CHOI', Dongkwan $\mathrm{LEE}^{2}$, Choongik $\mathrm{CHOI}^{3}$
}

Received: March 13, 2020. Revised: April 03, 2020. Accepted: May 05, 2020

\begin{abstract}
TThe cooperation on disaster prevention between the two Koreas has been mostly focused on cooperation at the recovery stage, such as emergency relief supplies and equipment support. This study aims to articulate future practical development plans by analyzing disaster cooperation between North and South Korea in accordance with the changing paradigm of international disaster cooperation. Considering the specificity of inter-Korean cooperation, the Framework for Inter-Korean Disaster Prevention Cooperation was established centering on the Sendai Framework for Disaster Risk Reduction. The framework consists of understanding and sharing disaster risks, building back better, strengthening community resilience, and supporting regional disaster action plans for continuous action. Inter-Korean disaster prevention cooperation requires sharing information about North Korean disasters. It is necessary to accurately identify and support social vulnerability to North Korean disasters. Above all, it is supporting the development of disaster action plans from a humanitarian perspective needs. A medium-to-long term resilience reinforcement plan that North Korea can resolve on its own is also needed. Since North Korea is also deeply interested in international disaster cooperation, it should be based on the direction of the Sendai Framework. Considering the uniqueness of inter-Korean cooperation, a path for North Korea to actively participate in international disaster cooperation should be established.
\end{abstract}

Keywords : Disaster Reduction, Sendai Framework, International Cooperation, Development Cooperation, North Korea

JEL Classification Code: D74, F42, I15, O21, O53

\section{Introduction}

Inter-Korean disaster prevention cooperation has the necessity of constitutional cause, humanitarian aid, and prevention of damage to Korea. Specifically, there are no

*This work was supported by the Ministry of Education of the Republic of Korea and the National Research Foundation of Korea(NRF2019S1A5A2A01035379).

${ }^{1}$ First Author, Postdoctoral Fellow, Department of Public Administration, Kangwon National University, Korea [Postal Address: 1 Gangwondaehakgil, Chunchen-Si, Gangwon-do, 24341, Korea]. Email: smolts80@gmail.com

2Postdoctoral Fellow, Department of Public Administration, Kangwon National University, South Korea. Email: brightlee9@gmail.com

${ }^{3}$ Corresponding Author, Professor, Department of Public Administration, Kangwon National University, Korea. Email: choich@kangwon.ac.kr

() Copyright: The Author(s)

This is an Open Access article distributed under the terms of the Creative Commons Attribution Non-Commercial License (http://Creativecommons.org/licenses/by-nc/4.0/) which permits unrestricted noncommercial use, distribution, and reproduction in any medium, provided the original work is properly cited. disaster response regulations associated with North Korea in disaster-related laws, including the framework act on disasters and safety management. However, it is Korea's cause and duty to respond to the disasters that occur on the Korean Peninsula, the territory of Korea as defined by the Constitution. In addition, disaster cooperation is important because humanitarian assistance is needed for the damages of North Koreans in the event of a disaster, and disasters in North Korea can cause great damage to South Korea.

South Korea's cooperation on disaster damage, or inter-Korean disaster prevention cooperation, began in 1995 when South Korea sent supplies to North Korea, which suffered natural disasters such as floods and droughts. Since then, South Korea has implemented a disaster prevention cooperation in support of food and food aid, such as rice, relief supplies such as medicines, and materials and defenses to restore destroyed housing and infrastructure. In the process, the two Koreas signed an agreement for disaster cooperation. However, due to the military confrontation at home and abroad, it also showed the limit of sustainability and effectiveness (Eberstadt, 
2007; Kim \& Kim, 2016). Moreover, disasters in North Korea need assistance from the humanitarian perspective of the Korean people. Measures are urgently needed in that damage can be extended to Koreans living in border areas.

In particular, flooding in the Imjin River basin and forest fires in the DMZ (Demilitarized Zone) occur almost every year, which is why the joint cooperation between the two Koreas is urgently needed. Since the adoption of the 'Yokohama Strategy and Plan of Action for a Safer World', the international community has adopted and applied the 'Hyogo Framework for Action' (2005-2015), 'Building the Resilience of Nations and Communities to Disasters (after HFA)', and the 'Sendai Framework for Disaster Risk Reduction 2015-2030'. The necessity and importance of international cooperation in the field of disaster prevention have globally increasing.

Under these circumstances, North Korea emphasized its high interest in international disaster cooperation by attending 'the Global Platform for Disaster Risk Reduction' held in May 2017 at Cancun, Mexico. For example, the Chairman of the State Committee for Emerging and Disaster Management of the Democratic People's Republic of Korea participated. He said he has taken various steps in North Korea since the establishment of the SFDRR for the past two years. In particular, he said that he is constantly striving to implement the SFDRR's goals and priorities. He expressed his willingness to cooperate with the international communities and a desperate commitment for international disaster cooperation. In particular, he expressed appreciation for the international community's cooperation in the rapid recovery through technical and human support for the flooding of North Hamgyong in 2016. This is very unusual for North Korea's administration, with Songun Politics in the background. This study aims to articulate future development plans by analyzing disaster cooperation between North and South Korea in accordance with the changing paradigm of international disaster cooperation.

Although there are many studies related to North Korea, the international literature on disaster prevention cooperation is very rare. In particular, this study is meaningful because there are few studies focusing on inter-Korean disaster prevention cooperation in the framework of international disaster cooperation, considering the situation of the Korean peninsula, which has changed rapidly since the installation of the new Korean government in 2017.

\section{Establishment of Inter-Korean Disaster Prevention Cooperation Framework Reflecting International Disaster Cooperation Paradigm}

\subsection{International Disaster Prevention Cooperation Paradigm Trends at the WCDRR}

Disaster countermeasure is changing from disaster prevention countermeasure focused on structural measures to disaster reduction with more emphasis on non-structural measures as the uncertainty of disaster increases.

The effectiveness of the disaster reduction countermeasure depends, among other things, on improving the responsiveness of the community. Whether or not the community can respond collectively is a key task for mitigation measures (Buckland \& Rahman, 1999; Matsuda \& Okada, 2006; Bajek et al., 2008; Maskrey, 2011; Samaddar et al., 2015; Samaddar et al., 2017, Choi \& Choi, 2018a, Choi \& Choi, 2018b; Choi et al, 2019; Song et al., 2019).

These measures began to attract international attention since 1994 at the 1st World Conference on Disaster Risk Reduction (WCDRR). This meeting was held for the mid-term inspection of the International Decade for Natural Disaster Reduction (IDNDR). Previously, international disaster cooperation had been aimed at disaster reduction through a scientific and technology approach, and the 1st WCDRR mainly discussed comprehensive issues (Press, 1985). Moreover, the significance of this meeting was the discussion of the paradigm shift from disaster response to proactive prevention and the Yokohama strategy as a guideline for international disaster cooperation. Following the end of the IDNDR's 10-year plan, from 1990 to 1999, the United Nations Office for Disaster Risk Reduction (UNISDR) was established in December 1999 to oversee the agency responsible for leading international disaster cooperation in the United Nations. In 2005, the 2nd WCDRR was held in Kobe, Japan. The meeting adopted the Hyogo Declaration, which, with the consent of all participating countries, laid out the mainstreaming of international disaster cooperation, and the HFA was published as a guideline. HFA is meaningful because it is a full-scale disaster prevention cooperation platform detailing methods, goals, and priorities for disaster risk reduction. The Hyogo Code of Conduct has underlined the significance of international disaster cooperation in overcoming developments that do not take into consideration disaster risks, which is a major obstacle to sustainable development and poverty reduction in developing countries. In 2015, the 3rd WCDRR was the largest conference ever on international disaster cooperation, bringing 
together $185 \mathrm{UN}$ member states and about 150,000 people. At the meeting, the main content of the Hyogo Code of Conduct was enshrined, and the new concepts, "Importance of disaster prevention investment" and "Build Back Better," were further proposed and improved. The Sendai Declaration containing this information was unanimously adopted and the SFDRR was published as a guideline (Olowu, 2010; Djalante et al., 2012; Kelman, 2015; Tozier \& Baudoin, 2015; Zia \& Wagner, 2015).

\subsection{Establishment of Inter-Korean Disaster Prevention Cooperation Frame}

For South Korea's disaster prevention support to have a more substantial effect on North Korea, it must be based on establishing a people-centered cooperation plan on how to protect North Korean citizens from disasters (Moon, 2000; Song, 2015). In other words, the inter-Korean disaster prevention cooperation should prepare a framework that can enhance practical capabilities unlike before. Cooperation should be made to increase the comprehensive capacity of North Korea's disasters. The cooperation should not end with the North's assistance only and the restoration before the disaster. However, since the two Koreas have special relations that do not originate in international and politicalmilitary terms, the following particularities should be considered.

First, inter-Korean relations must be based, above all, on mutual trust. It should not be simply a support for maintaining the system and cooperation of aspirations, but cooperation that can maintain a good relationship to increase mutual benefits (Lewicki et al., 1996). In particular, fighting infectious diseases such as malaria and swine flu have been established through cooperation between the two Koreas based on trust. On the other hand, the two Koreas agreed to implement the Imjin River flood prevention project through ministerial talks in 2000; several meetings have been held.

Second, since it is directly related to life beyond other inter-Korean cooperation issues, it is important not to focus on military and security issues. The DMZ is a global ecosystem of conservation area and needs protection. It is estimated that more than 80 wildfires have occurred in the border region including the DMZ from 2005 to 2015 . However, due to issues such as the Armistice Agreement, the firefighting response is limited, and through the UN command, firefighting helicopters are allowed to enter the area. The inter-Korean disaster cooperation framework based on SFDRR is as follows.

First, understand and share North Korea's disaster risks. Disaster risk is not only focused on existing hazards, but is shifting risk awareness that it may be an inherent factor in North Korea's development process. In other words, disaster risks require cooperation, noting external factors such as natural hazards, but also the endogenous nature of North Korea itself.

Second, as a way to strengthen disaster risk management, regional resilience is raised. Strengthening resilience is linked to SDGs' sustainable development in that they build a disaster-resistant society. Resilience reinforcement is an essential element in the present situation where a close approach to the major paradigms for international cooperation is important. On recovery, build back better should be realized. After a disaster, it is important to take measures against various problems that are expected to occur during recovery. It is necessary to implement a plan that has been thoroughly reviewed before restoration, including how to use land safely and rebuild critical facilities.

Third, support the establishment of humancentered disaster action plans that can be continuously implemented. The important significance of SFDRR is to broaden the horizon from disasters to the risks of disasters, emphasizing the need for more fundamental management related to disasters. The policy paradigm of disasters has been shifted, and more emphasis has been placed on establishing people-centered policies than before. Disaster relief through human behavior that does not rely solely on science and technology, which has been pointed out since 1994, can only be reflected in SFDRR. SFDRRs are formed through formal or informal institutional arrangements between stakeholders and organizations to reduce disaster risks. SFDRR emphasizes the decentralization of disaster management for systematic improvement, capacity-building to cope with various disasters, knowledge sharing and communication for wider stakeholder engagement (Tierney, 2012; Trogrlic et al., 2017).

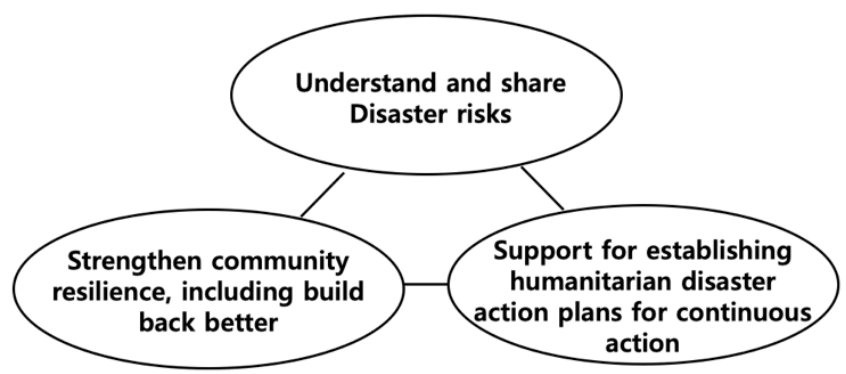

Figure 1: Three Points of Inter-Korean Disaster Prevention Cooperation Considering Sendai Framework 


\section{Disaster Prevention Cooperation Development Plan}

\subsection{Understanding and Sharing Disaster Risks}

To understand North Korea's disaster risks, it is important to share information about North Korea's disasters. The information on hazard, which is a factor of natural disaster, can be obtained through science and technology, but the factor of social vulnerability is difficult to grasp. The information delivery system, response method, and support system for disasters in North Korea are important factors in understanding North Korea's management of disaster risks. However, the official information and statistics on how the North Korean authorities specifically implemented disaster management are not well known. For example, the outbreak of the African swine fever virus (ASFV) that occurred on the Korean peninsula in 2019 was widely spread around the border with North Korea.

To prevent the spread of the ASF virus, appropriate measures should be promptly implemented in the area. However, North Korea has not submitted additional information since May 2019, when the first ASF occurred. OIE (Office International des Epizooties) also expressed strong concern about the spread of ASF outbreaks on the Korean peninsula and demanded North Korea's transparency regarding the status of infection. If a disaster occurs, it is obvious that North Korea, its party, is primarily responsible. However, due to North Korea's economic limitations, it has not been properly supported, and cooperation between the international communities, including South Korea, is urgently needed. Looking at the assistance to North Korea so far, there is a tendency to provide only emergency rescue and relief supplies in the event of a disaster. To prevent disasters that may occur again, systems aimed at sharing information on disaster risks should be in place.

In the inter-Korean basic agreement, adopted in 1991, the two Koreas agreed to implement exchange and cooperation in similar areas such as health and the environment, but there is no specific agreement on disasters. It would be desirable to direct disaster cooperation in a macroscopic manner and to promote detailed cooperation by hazards such as floods and earthquakes.

Inter-Korean cooperation has a variety of external factors that can be stopped due to the peculiarities of inter-Korean relations. Considering that the inter-Korean cooperation system is not continually implemented, it is also important to collect accurate information on disaster risks through international organizations.

In the case of the 2006 flood damage in the Tumen River region, various international organizations cooperated to support flood damage in North Korea, and a final report was prepared. As mentioned above, South Korea should participate in the activities of international organizations on North Korean disasters and use relevant information. It will be important to look for sustainable, well-established ways of cooperation through understanding and sharing disaster risks.

\subsection{Strengthening Community Resilience, Including Build Back Better}

Most of the international community's assistance to North Korea, which began in 1995, remains in emergency aid. However, if we look at the disasters in North Korea, the flooding of North Korea occurs almost every year because these aid supplies are only short-term. Disaster cooperation must be freed from the humanitarian aid phase of disasters. It should be gradually expanded to understand and support North Korea's social vulnerability through understanding disaster risk. In other words, long-term investment is needed to reinforce the resilience of North Korea's disaster zones.

Inter-Korean cooperation with North Korea needs practical measures to strengthen the resilience of North Korea's disaster-vulnerable communities in consideration of the entire process of disaster management. In particular, it is necessary to directly or indirectly support the goal, as the first priority is to ensure that North Koreans in the region are not killed by the disaster. Long-term cooperation is needed, including the creation of action manuals for reducing disaster risks and supporting learning and training systems. To this end, it may include not only inter-Korean cooperation, but also measures to derive cooperation with international organizations.

Disaster cooperation should also be linked to development cooperation, in the long run, to strengthen resilience. Longterm support is needed to strengthen North Korea's ability to prevent and respond to disasters on its own. Until now, disaster cooperation between the two Koreas has been insufficient to understand and share disaster risks and to strengthen the resilience of the North Korean community. This is because disaster cooperation between the two Koreas remained only for short-term emergency aid. Looking at the international community's support for floods in North Korea in 2006, it is not far from the framework of emergency aid supplies. This view of support did not differ significantly when supporting recovery. If the understanding of disaster risks and the reinforcement of resilience are not taken into account when supporting recovery materials, communities will be harmed again when the same disaster occurs. In other words, when restoring, considering build back better needs.

It is well known that North Korea's social vulnerability to disaster is low. The poor quality of living conditions, lack 
of disaster prevention infrastructure, food shortages and economic difficulties are all factors. When recovering, it is necessary to consider build back better, prioritize, and start comprehensive development support. For recovery, disaster management should be continuously carried out through the establishment of infrastructure in terms of urban regeneration and environmentally friendly policies considering disaster prevention.

\subsection{Supporting Local Disaster Action Plans for Continuous Action}

Inter-Korean disaster prevention cooperation was first carried out in 1995 through floods. Since then, South Korea has provided relief supplies and recovery equipment for most disaster prevention cooperation. However, due to the international and political crunch of the two Koreas, cooperation was frequently stopped and some aspects could not be implemented even though an agreement on disaster prevention cooperation was signed. In other words, disaster cooperation between the two Koreas is very difficult to sustain.

For example, the inter-Korean border is global ecosystem conservation area and needs protection, but it is estimated that at least 80 wildfires have occurred in the border areas (including the DMZ) from 2005 to 2015. The border area has limited firefighting capabilities due to issues such as the Armistice Agreement, and firefighting helicopters are authorized to enter the area through the UN Command, but it is changing depending on the situation of inter-Korean relations.

In fact, in April 2018, ahead of the inter-Korean summit, a fire broke out around the border at Yeoncheon-gun, Gyeonggi-do. Although many firefighting helicopters were used, it took much time to operate due to the lack of a joint cooperation system for inter-Korean cooperation. Disaster cooperation between the two Koreas should be sustained, but humanitarian perspectives will be needed to support measures that can solve the damage as much as possible. From a macro perspective, this will be a critical opportunity to recognize the necessity of disaster cooperation and to expand the need for cooperation with South Korea.

It is necessary to first establish a disaster action plan. This can be specifically distinguished from inside and outside of North Korea.

Above all, it is important to establish a specific evacuation plan to cope with disasters, with the top priority being that no human injury occurs internally. The coordination of disasterrelated stakeholders in the North Korean community should be facilitated. Externally, considering that inter-Korean

Table 1: Implementation Strategies by Agenda

\begin{tabular}{|c|c|}
\hline Agenda & lain Contents \\
\hline $\begin{array}{l}\text { Understand and } \\
\text { share disaster risks }\end{array}$ & $\begin{array}{l}\text { Essential conditions for continued inter-Korean cooperation } \\
\text { There is insufficient information on disaster management implementation in North Korea } \\
\text { Need to understand social vulnerability rather than hazard } \\
\text { Prepare measures to utilize international organizations in consideration of the suspension of inter- } \\
\text { Korean cooperation } \\
\text { Need to improve the system for sharing disaster risk information }\end{array}$ \\
\hline $\begin{array}{l}\text { Strengthen } \\
\text { community resilience, } \\
\text { including build back } \\
\text { better }\end{array}$ & $\begin{array}{l}\text { Need as a follow-up to understanding and sharing disaster risks } \\
\text { Inter-Korean cooperation is promoted considering the entire process of disaster management } \\
\text { Connection with development cooperation } \\
\text { Execute according to priority, considering build back better when recovering }\end{array}$ \\
\hline $\begin{array}{l}\text { Support for } \\
\text { establishing } \\
\text { humanitarian disaster } \\
\text { action plans for } \\
\text { continuous action }\end{array}$ & $\begin{array}{l}\text { It can act as a decisive factor in the recognition and expansion of the need for cooperation between } \\
\text { the two Koreas } \\
\text { A disaster action plan is established by dividing North Korea internally and externally } \\
\text { Internally, it is a priority that no human injury occurs, and a specific regional evacuation plan is } \\
\text { established } \\
\text { Externally, it is necessary to ensure that disaster prevention cooperation can be carried out } \\
\text { simultaneously at the inter-Korean level and the international community level }\end{array}$ \\
\hline Common ground & $\begin{array}{l}\text { Improvement from short-term support to long-term support } \\
\text { Prepare measures to utilize international organizations in consideration of the suspension of inter- } \\
\text { Korean cooperation } \\
\text { Start with the easy ones in cooperation with North Korea, then gradually expanded } \\
\text { Select and promote those that can be translated into a short-term effect of disaster prevention } \\
\text { cooperation } \\
\text { Develop and promote issues that are not affected by the international and inter-Korean situation }\end{array}$ \\
\hline
\end{tabular}


relations and international politics are crunched, inter-Korean disaster prevention cooperation will be affected. Disaster prevention cooperation should ensure that the inter-Korean level and the level of international community participation can be promoted simultaneously.

At this time, it is necessary to start easy cooperation with North Korea and gradually expand it. Selecting those which can see the effects of disaster prevention cooperation in a short period, and developing and promoting issues that are not affected by the situation of the two Koreas are needed.

\section{Discussion and Conclusions}

\subsection{Summary}

This study examined the ways for disaster cooperation between North and South Korea based on the paradigm of international disaster cooperation. It investigated the trends in disaster prevention cooperation based on the WCDRR, which began in 1994, and the guidelines for international disaster prevention cooperation.

It considered the specificity of inter-Korean cooperation, focusing on SFDRR, which is the most recent guideline for international disaster prevention cooperation. It established a framework for inter-Korean disaster prevention cooperation consisting of understanding and sharing disaster risks, strengthening community resilience including build back better, and supporting regional disaster action plans for continuous action as well. Disaster prevention cooperation between the two Koreas has not been sustained due to shortterm relief aid or political situation.

If this particularity is not considered, it may not be effective for practical disaster cooperation. In particular, in order for South Korea's disaster prevention support to have a practical effect, it should be based on establishing cooperation plans centering on disaster prevention for North Korean citizens.

In the future development of disaster cooperation, it is important to share information about North Korea's disasters to understand North Korea's disaster risks. Understanding disaster risks accurately identifies North Korea's social vulnerability. In support of this, it should be gradually expanded to help strengthen community resilience. We concluded that it is necessary to first establish a disaster action plan by supporting measures to solve the damages as much as possible.

\subsection{Limitation and Implication}

Like other inter-Korean cooperation, North Korea is unlikely to voluntarily request assistance from South Korea without economic benefits. Also, the lack of a systematic approach for sustainable inter-Korean disaster prevention cooperation is one of the major limitations. Disaster management collaborative governance is very important in terms of the administrative system, but North Korea's special system may limit the acceptance of such advice. Since North Korea conducted a nuclear test, inter-Korean cooperation has been cut off from time to time and sanctions have been tightened in the international community.

It is also impossible to carry out inter-Korean disaster prevention cooperation with the international community at once. But even with limitations, it is very important to try something. North Korea has publicly announced its high interest in disaster prevention cooperation and will actively follow SFDRR.

As pointed out by this study, future inter-Korean disaster cooperation should be established as a system to support understanding and sharing of disaster risks, strengthening resilience, and establishing regional action plans. In addition, the provision of ongoing support through cooperation with the international community should be a priority. North Korea needs to strengthen its resilience to solve the disasters that occur every year. Recovery from future disasters should be supported in terms of build back better and the disaster should be prevented from recurring.

SFDRR has already emphasized international cooperation through financial support for developing countries and expansion of cooperation platform, and it can be used actively for inter-Korean disaster prevention cooperation. Therefore, North Korea should devise incentives to actively participate in disaster management and lead inter-Korean disaster cooperation in the direction sought by SFDRR.

Lastly, to reduce social vulnerability and strengthen capacity for disasters, North Korea should start with easy ones, which can be achieved in the short term, and mid- and long-term cooperation should be premised. To this end, interKorean disaster prevention cooperation should be promoted in such a way as to establish priorities for cooperation and to benefit for the two Koreas.

\section{References}

Bajek, R., Matsuda, Y., and Okada, N. (2008). Japan's Jishubosai-soshiki community activities: Analysis of its role in participatory community disaster risk management. Natural Hazards, 44(2), 281-292.

Buckland, J., \& Rahman, M. (1999). Community-based disaster management during the 1997 Red River Flood in Canada. Disasters, 23(2), 174-191.

Choi, C., \& Choi, J. (2018a). Development and distribution of risk governance framework in terms of socially viable solutions. The Journal of Asian Finance, Economics and Business. 5(3), 185-193. 
Choi, C., \& Choi, J. (2018b). Distribution and application of community-based disaster risk information: Lessons from Shiga Prefecture in Japan. Journal of Distribution Science, 16 (6), 15 15-23.

Choi, C., Tatano, H., \& Choi, J. (2019). Development and application of a sense-making approach to community-based disaster risk governance. Journal of Asian Finance. Economics and Business Business, 6(1), 289-301.

Djalante, R., Thomalla, F., Sinapoy, M. S., \& Carnegie, M. (2012). Building resilience to natural hazards in Indonesia: Progress and challenges in implementing the Hyogo Framework for Action. Natural Hazards, 62(3), 779-803.

Eberstadt, N. (2007). The North Korean Economy: Between Crisis and Catastrophe. New Brunswick, NJ: Transaction Publishers.

Kelman, I. (2015). Climate change and the Sendai framework for disaster risk reduction. International Journal of Disaster Risk Science, 6, 117-127.

Kim, J., \& Kim, J. (2016). The Relationship between Social Support and Acculturative Stress from Cultural Adaptation of People Displaced from North Korea to South Korea. China Journal of Social Work, 9(1), 3-24.

Maskrey, A. (2011). Revisiting community-based disaster risk management. Environment Hazards, 10(1), 42-52.

Matsuda, Y., and Okada, N. (2006). Community diagnosis for sustainable disaster preparedness. Journal of Natural Disaster Science, 28(1), 25-33.

Moon, C. (2000). The Sunshine Policy and the Korean Summit: Assessments and Prospects. East Asian Review, 12(4), 3-36.

Olowu, D. (2010). The Hyogo Framework for Action and its implications for disaster management and reduction in Africa. Journal of Disaster Risk Studies, 3(1), 303-320.

Pearce, L. (2003). Disaster management and community planning, and public participation: How to achieve sustainable hazard mitigation. Natural Hazards, 28(2-3), 211-228.
Press, F. (1985) The Role of Science and Engineering in Mitigating Natural Hazards. Bulletin of the New Zealand National Society for Earthquake Engineering, 18(2), 115-118.

Roy, J. L., Alexander, H., \& Karen, W. O. (1996). Think before You Speak. N.Y.: John Wiley.

Samaddar, S., Choi, J. H., Misra, B. A., \& Tatano. H. (2015). Insights on social learning and collaborative action plan development for flood risks mitigation: Practicing yonmenkaigi system method (YSM) in hotspot Mumbai. Natural Hazards, 75(2), 1531-1554.

Samaddar, S., Okada, N., Choi, J., \& Tatano, H. (2017). What constitutes successful participatory disaster risk management? Insights from post-earthquake reconstruction work in rural Gujarat, India. Natural Hazards, 85(1), 111-138.

Song, W., Choi, J., Lee, D., \& Choi, C. (2019). Development of a Customer Friendly GIS-based Disaster Management System in South Korea. Journal of Distribution Science, 17(11), 27-34.

Tierney, K. (2012). Disaster Governance: Social, Political, and Economic Dimensions. Annual Review of Environment and Resources, 37, 341-363.

Tozier de la Poterie, A., \& Baudoin, M. A. (2015). From Yokohama to Sendai: Approach to participation in international disaster risk reduction frameworks. International Journal of Disaster Risk Reduction, 6(2), 128-139.

Trogrlic, R. S., Cumiskey, L., Triyanti, A., Duncan, M. J., Eltinay, N., Hogeboom, R. J., Jasuja, M., Meechaiya, C., Pickering, C. J. \& Murray, V. (2017). Science and technology networks: a helping hand to boost implementation of the Sendai Framework for Disaster Risk Reduction 2015-2030? International Journal of Disaster Risk Reduction, 8(1), 100-105.

Zia, A., \& Wagner, C. H. (2015). Main streaming early warning systems in development and planning processes: Multi level implementation of Sendai framework in Indus and Sahel. International Journal of Disaster Risk Science, 6, 189-199. 